T. V. Abramova

\title{
The distribution of the islets of Langerhans in pancreas of euglycemic spontaneously hypertensive rats
}

\author{
Zaporizhzhia State Medical University \\ Key words: Hypertension, Islets of Langerhans, Insulin. \\ Considering the fact, that pancreatic beta cells are responsible for production of all insulin needed to maintain the glucose homeo- \\ stasis, the problem of beta cells pull control in patients with hypertension is rather topical. It cannot be ruled, that genetical defects of \\ congenital hypertension formation can affect the mechanisms of maintaining of the cell mass of pancreatic endocrinocytes and lead to \\ violation of glucose metabolism and diabetes mellitus development. Moreover, the violation of cytoarchitectonics of pancreatic islets of \\ Langerhans may lead to impairment of the insulin secretion, which can be due to local impairment of the blood circulation in patients \\ with hypertension.
}

The aim was to study the features of SHR islets' distribution in pancreas.

Materials and methods. The glucose blood level and the insulin concentration were measured from tail vein. The immunofluorescence analysis was made and data were processed with statistical application kit with evaluation of reliability of differences in experimental groups with Student's t-criterion.

Results. The object of current study was the animals with fasting normoglycemia and Wistar rats with $3.94 \mathrm{mmol} / \mathrm{l}$ fasting glucose level. The morphometrical assay showed $78.8 \%$ of pancreatic islets in SHR are small islets, while in Wistar rats their share is $44.3 \%$. Noteworthy is the great amount of solely beta-cells in SHR and total absence of large islets.

Conclusions. The violation of pancreas' cytoarchitectonic and changes of islets' distribution with prevailing of small islets with area less than $1500 \mu \mathrm{m}^{2}$ were observed.

Beta-cells in normoglycemic SHR were characterized with 2-fold increased concentration of immunoreactive insulin compared with normotensive Wistar rats.

\section{Особливості розподілу острівців Лангерганса в підшлунковій залозі еуглікемічних щурів лінії SHR}

\section{T. В. Абрамова}

3 огляду на те, що панкреатичні бета-клітини відповідальні за виробництво всього інсуліну, що необхідний організму для підтримки глюкозного гомеостазу, проблема контролю пула бета-ендокриноцитів у пацієнтів із гіпертонічною хворобою $\epsilon$ актуальною, оскільки не виключено, що генетичні дефекти формування спадкової артеріальної гіпертензії розвитку можуть стосуватись механізмів підтримки клітинної маси ендокриноцитів у підшлунковій залозі й призводити до порушення метаболізму глюкози та діабету. Крім того, до порушення адекватної секреції інсуліну підшлунковою залозою може призводити порушення цитоархітектоніки панкреатичних острівців, що може бути спровоковано регіональними порушеннями кровообігу в пацієнтів 3 артеріальною гіпертензією.

Мета роботи - вивчити параметри розподілу панкреатичних острівців у підшлунковій залозі гіпертензивних щурів лінії SHR.

Матеріали та методи. Виміряли рівень глюкози крові та концентрацію інсуліну, а також аналіз імунофлюоресцентної реакції. Дані опрацювали пакетом статистичних програм, для оцінювання вірогідності відмінностей у групах застосовували t-критерій Стьюдента.

Результати. Морфометричний аналіз показав, що у гіпертензивних щурів лінії SHR 78,8\% панкреатичних острівців підшлункової залози представлені маленькими острівцями, тоді як у нормотензивних щурів лінії Wistar їхня частка становить 44,3\%. Привертає увагу велика кількість одиничних бета-ендокриноцитів у підшлунковій залозі щурів лінії SHR i повна відсутність великих острівців. Поряд з тим зменшення чисельності бета-клітин у залозі щурів лінії SHR значною мірою компенсувалося вищою концентрацією імунореактивного інсуліну в ендокриноцитах, що, ймовірно, забезпечувало збереження достатнього рівня імунореактивного інсуліну в периферичній крові та підтримку еуглікемічних показників натщесерце.

Висновки. Цитоархітектоніка підшлункової залози в гіпертензивних щурів лінії SHR характеризується порушенням розподілу панкреатичних острівців і домінуванням малих острівців. Бета-клітини у нормоглікемічних гіпертензивних щурів лінії SHR характеризуються вдвічі вищою, ніж у нормотензивних щурів лінії Wistar, концентрацією імунореактивного інсуліну.

Ключові слова: гіпертензія, панкреатичні острівці, інсулін.

Патологія. - 2016. - №1 (36). - С. 19-21

\section{Особенности распределения островков Лангерганса в поджелудочной железе эугликемических крыс} линии SHR

\section{T. В. Абрамова}

Учитывая то, что панкреатические бета-клетки ответственны за производство всего инсулина, необходимого организму для поддержания глюкозного гомеостаза, проблема контроля пула бета-эндокриноцитов у пациентов с гипертонической болезнью является актуальной, так как не исключено, что генетические дефекты формирования наследственной артериальной гипертензии развития могут затрагивать механизмы поддержания клеточной массы эндокриноцитов в поджелудочной железе и приводить к нарушению метаболизма глюкозы и диабету. Кроме того, к нарушению адекватной секреции инсулина поджелудочной железой 
может приводить нарушение цитоархитектоники панкреатических островков, что может быть спровоцировано региональными нарушениями кровообращения у пациентов с артериальной гипертензией.

Цель работы - изучить параметры распределения панкреатических островков в поджелудочной железе у гипертензивных крыс линии SHR.

Материалы и методы. Измерили уровень глюкозы в крови и концентрацию инсулина, а также анализ иммунофлюоресцентной реакции. Полученные данные обрабатывали пакетом статистических программ, для оценки достоверности различий в группах применяли t-критерий Стьюдента.

Результаты. Морфометрический анализ показал, что у гипертензивных крыс линии SHR 78,8\% панкреатических островков поджелудочной железы представлены маленькими островками, тогда как у нормотензивных крыс линии Wistar их доля составляет $44,3 \%$. Обращает внимание большое количество единичных бета-эндокриноцитов в поджелудочной железе крыс линии SHR и полное отсутствие крупных островков. Вместе с тем уменьшение численности бета-клеток в железе у крыс линии SHR в значительной мере компенсировалось более высокой концентрацией иммунореактивного инсулина в эндокриноцитах, что, вероятно, обеспечивало сохранение достаточного уровня иммунореактивного инсулина в периферической крови и поддержание эугликемических показателей натощак.

Выводы. Цитоархитектоника поджелудочной железы у гипертензивных крыс линии SHR характеризуется нарушением распределения панкреатических островков и доминированием малых островков. Бета-клетки у нормогликемических гипертензивных крыс линии SHR характеризуются в 2 раза более высокой, чем у нормотензивных крыс линии Wistar, концентрацией иммунореактивного инсулина.

Ключевые слова: гипертензия, панкреатические островки, инсулин.

Патология. - 2016. - №1 (36). - С. 19-21

$\mathrm{H}$ ypertension and diabetes mellitus are the diseases with steadily increasing morbidity in population of many countries. [8,12]. It had long been considered, that arterial hypertension and diabetes mellitus are not mutually generated diseases, however their comorbidity is proved $[8,11,12]$. Considering the fact, that pancreatic beta cells are responsible for production of all insulin needed to maintain the glucose homeostasis, the problem of beta cells pull control in patients with hypertension is rather topical. It cannot be ruled, that genetical defects of congenital hypertension formation can affect the mechanisms of maintaining of the cell mass of pancreatic endocrinocytes and lead to violation of glucose metabolism and diabetes mellitus development $[5,9]$. Moreover, the violation of cytoarchitectonics of pancreatic islets of Langerhans may lead to impairment of the insulin secretion $[7,10]$, which can be due to local impairment of the blood circulation in patients with hypertension.

The aim was to study the features of SHR islets' distribution in pancreas.

\section{Materials and methods}

The study was carried out in 10 normotensive male Wistar rats (systolic blood pressure is $105.0 \pm 1.1 \mathrm{~mm} \mathrm{Hg}$ ) and 15 hypertensive mail rats (systolic blood pressure is $155.7 \pm 0.9$ $\mathrm{mm} \mathrm{Hg}$ ) in age of 5-6 months. The glucose blood level from tail vein was measured with glucometer (GlucoCard-II, Japan), the insulin concentration was measured with ELISA kit (DRG, USA). In histological slices of 5-micrometer taken from different parts of pancreas the insulin was detected with immunofluorescence assay after 20-hour incubation with insulin antibodies and 1-hour incubation with c IgG conjugated with FITC (Peninsula Lab. Inc., Great Britain). The immunofluorescence analysis was made with the fluorescence microscope AxioImager-A2 (Carl Zeiss, Germany) and the system of digital image analysis AxioVision (Carl Zeiss, Germany). Data were processed with statistical application kit with evaluation of reliability of differences in experimental groups with Student's t-criterion.

\section{Results}

We have previously shown [6], that spontaneously hypertensive rats can be divided into 3 groups according to the fasting glycemia level: animals with normoglycemia $(n=15$, $32 \%)$, with impaired glucose tolerance $(n=18.38 \%)$ and with hyperglycemia $(n=14.30 \%)$. The object of current study was the animals with fasting normoglycemia $(4.73 \pm 0.10 \mathrm{mmol} / \mathrm{l})$ and Wistar rats with $3.94 \pm 0.09 \mathrm{mmol} / 1$ fasting glucose level.

The morphometrical assay showed $78.8 \pm 7.7 \%$ of pancreatic islets in SHR are small islets with area less than 1500 $\mu \mathrm{m}^{2}$, while in Wistar rats their share is $44.3 \pm 5.8 \%$ (Table 1).

\section{The density of allocation of pancreatic islets (per $100 \mathrm{~mm}^{2}$ of area of a pancreas slice) in SHR and Wistar rats $(\mathrm{M} \pm \mathrm{m})$}

\begin{tabular}{|c|c|c|c|}
\hline Islets' type & Wistar rats & SHR rats & Reliability \\
\hline Single beta cells & $4.1 \pm 0.6$ & $11.9 \pm 1.3$ & $\mathrm{p}<0,001$ \\
\hline Small, area $<1500 \mu \mathrm{m}^{2}$ & $102.5 \pm 13.5$ & $95.9 \pm 9.4$ & $\mathrm{p}>0,05$ \\
\hline Medium, area $1500-3500 \mu \mathrm{m}^{2}$ & $70.7 \pm 4.5$ & $11.0 \pm 1.4$ & $\mathrm{p}<0,001$ \\
\hline Large, area $3500-7500 \mu \mathrm{m}^{2}$ & $30.7 \pm 4.7$ & $3.2 \pm 1.2$ & $\mathrm{p}<0,001$ \\
\hline Giant, area $>7500 \mu \mathrm{m}^{2}$ & $23.1 \pm 4.3$ & $0 \pm 0$ & $\mathrm{p}<0,001$ \\
\hline
\end{tabular}

Noteworthy is the great amount of solely beta-cells in SHR (9.7 $\pm 1.1 \%$ compared with $0.04 \pm 0.006 \%$ in Wistar rats) and total absence of islets with area above $7500 \mu \mathrm{m}^{2}$. It should be noted, that the distribution of pancreatic islets of adult SHR rats largely corresponds to the distribution of Wistar rats in age of one month after the change of embryonal betacells type to adult type, and in young Wistar rats underwent chronic prenatal stress [1].

It has been noted earlier the hypertension formation in SHR was accompanied by age-related changes on insular apparatus of pancreas with decrease of beta-cells pull [2], which significantly differs from age-related evolution of 
pancreatic islets in Wistar rats. [4]. At the same time the decrease of beta-cells amount in SHR was largely compensated by higher concentration of immunoreactive insulin in endocrinocytes $(2.54 \pm 0.14$ conventional milliUnits $(\mathrm{mU})$ compared with $1.17 \pm 0.06 \mathrm{mU}$ in Wistar rats). This is likely to provide the maintenance of a sufficient level of immunoreactive insulin in peripheral blood flow $(10.99 \pm 0.37$ $\mu \mathrm{ME} / \mathrm{ml}$ compared with $8.61 \pm 0.41 \mu \mathrm{ME} / \mathrm{ml}$ in Wistar rats) and maintain of fasting euglycemia. However, taking into account the higher levels of blood concentration of lipids, triglycerides and cholesterol in SHR compared with Wistar rats $[3,6]$. It should be assumed, that normoglycemic status of hypertensive rats should not be considered as index of physiological state of carbohydrate homeostasis in these rodents, since a presence of lipid metabolic violations subsequently could contribute to the impairment of glucose tolerance and metabolic syndrome formation.

\section{Conclusions}

1. It has been observed the violation of pancreas' cytoarchitectonic and changes of islets' distribution with prevailing of small islets with area less than $1500 \mu \mathrm{m}^{2}$.

2. Beta-cells in normoglycemic SHR were characterized with 2-fold increased concentration of immunoreactive insulin compared with normotensive Wistar rats.

Prospects for the future research is related to the study of pancreatic islets' remodeling due to arterial hypertension.

Conflicts of Interest: authors have no conflict of interest to declare.

\section{References}

1. Abramov, A. V., Tikhonovskaya, M. A., \& Kolesnik, Yu. M. (2004). Osobennosti vliyaniya khronicheskogo prenatal'nogo stressa na strukturno-funkcional'nuyu organizaciyu beta$\mathrm{e}^{\prime}$ ndokrinocitov [Features of the influence of the chronic prenatal stress to structural and functional organization of beta endocrinocites]. Klinichna ta eksperymentalna, patolohiia, 2(1), 176-179. [in Ukrainian].

2. Grekova, T. A. (2010). Vliyanie prenatal'noj giperglikemii na morfofunkcional'noe sostoyanie e'ndokrinnogo apparata podzheludochnoj zhelezy samcov krys v vozrastnoj dinamike [The influence of prenatal hyperglycemia to morphofunctional state of endocrine apparatus of pancreas in male rats within the age dynamics]. Zaporozhskij medicinskij zhurnal, 12(4), 12-15. [in Ukrainian].

3. Kolesnik, Yu. M., Gancheva, O. V., Abramov, A. V., \& Kamyshnyj, A. M. (2007). Krysy linii SHR so spontannoj gipertenziej kak model' dlya izucheniya metabolicheskikh narushenij [Spontaneously hypertensive rats as the model for metabolic violations study] Zaporozhskij medicinskij zhurnal, 1, 5-10. [in Ukrainian].

4. Kolesnik, Yu. M., Grekova, T. A., Abramov, A. V., \& Tikhonovskaya, M. A. (2009). Osobennosti postnatal'nogo morfogeneza insulyarnogo apparata podzheludochnoj zhelezy samcov krys [Features of the postnatal morphogenesis of the insular apparatus of the pancreas in male rats]. Patologiya, 6(3), 67-68. [in Ukrainian].
5. Ackermann, A. \& Gannon, M. (2007). Molecular regulation of pancreatic beta-cell mass development, maintenance, and expansion. Journal Of Molecular Endocrinology, 38(2), 193-206.

6. Gancheva, O., Kolesnik, Y., Abramova, T., Samoylenko, N., \& Abramov, A. (2013). Metabolic disturbances in hypertensive rats. Clinichna Pahrmacia, 17(4), 56-58.

7. Jennings, R., Berry, A., Strutt, J., Gerrard, D., \& Hanley, N. (2015). Human pancreas development. Development, 142(18), 3126-3137. doi: 10.1242/dev.120063.

8. Jia, G., DeMarco, V., \& Sowers, J. (2015). Insulin resistance and hyperinsulinaemia in diabetic cardiomyopathy. Nat Rev Endocrinol, 12(3), 144-153. doi:10.1038/nrendo.2015.216.

9. Jonker, S. \& Louey, S. (2016). Endocrine and other physiologic modulators of perinatal cardiomyocyte endowment. $J$ Endocrinol, 228(1), R1-R18. doi: 10.1530/JOE-15-0309.

10. Kelly, C., McClenaghan, N., \& Flatt, P. (2011). Role of islet structure and cellular interactions in the control of insulin secretion. Islets, 3(2), 41-47. doi: 10.4161/isl.3.2.14805.

11. Mandavia, C., Aroor, A., DeMarco, V., \& Sowers, J. (2013). Molecular and metabolic mechanisms of cardiac dysfunction in diabetes. Life Sciences, 92(11), 601-608. doi: 10.1016/j. 1fs.2012.10.028.

12. Roglic, G. \& Unwin, N. (2010). Mortality attributable to diabetes: Estimates for the year 2010. Diabetes Research And Clinical Practice, 87(1), 15-19. doi: 10.1016/j.diabres.2009.10.006.

\section{Information about author:}

Abramova T. V., Assistant of the Department of Pediatrics of PGF, Zaporizhzhia State Medical University,

E-mail: abramov@zsmu.pp.ua.

Відомості про автора:

Абрамова Т. В., асистент каф. дитячих хвороб ФПО, Запорізький державний медичний університет, E-mail: abramov@zsmu.pp.ua.

Сведения об авторе:

Абрамова Т. В., ассистент каф. детских болезней ФПО, Запорожский государственный медицинский университет,

E-mail: abramov@zsmu.pp.ua. 